\title{
Reproductive phenology in a riparian rainforest in the south of Santa Catarina state, Brazil
}

\author{
MAINARA F. CASCAES ${ }^{1}$, VANILDE CITADINI-ZANETTE ${ }^{2}$ and BIRGIT HARTER-MARQUES ${ }^{1,2}$ \\ ${ }^{1}$ Laboratório de Interação Animal-Planta, UNAHCE, Universidade do Extremo Sul Catarinense/UNESC, \\ Av. Universitária, 1105, Bairro Universitário, 88806-000 Criciúma, SC, Brasil \\ ${ }^{2}$ Programa de Pós-Graduação em Ciências Ambientais, UNAHCE, Universidade do Extremo Sul Catarinense/UNESC, \\ Av. Universitária, 1105, Bairro Universitário, 88806-000 Criciúma, SC, Brasil
}

Manuscript received on June 12, 2012; accepted for publication on April 15, 2013

\begin{abstract}
Phenological studies assist in forest ecosystems comprehension and evaluation of resource availability for wildlife, as well as in improving the understanding of relationships between plants and their pollinators and dispersers. This study aims to describe the reproductive phenophases of riparian plant species and correlate them with climatic variables. The reproductive phenology was analyzed biweekly throughout one year, recording the absence or presence of flowers/fruits. The flowering phenophase occurred throughout the year, with an increase in number of species in blossom in October, November, and December. The flowering peak of the community was observed in November. The fruiting phenophase also occurred throughout the year and showed an increase of species fruiting in June with a slight decrease in August and September. The data obtained in this study, when compared with other studies in different Atlantic Rainforest areas, indicates a seasonal pattern for the flowering phenophase and a variation in fruit availability throughout the year as well as in the fruiting peaks. Therefore, studies that observe flowering and fruiting events in loco are of main importance because they provide information on reproductive seasons of species for use in environmental restoration projects and thus alleviate the situation of degradation of riparian forests.
\end{abstract}

Key words: flowering, fruiting, riparian forest, climatic variables.

\section{INTRODUCTION}

Phenology is the study of repetitive biological events and the factors that lead to its occurrence (Lieth 1974), which aid in the understanding of forest ecosystems (Morellato 1992), assessment of resource availability for fauna (Reys et al. 2005), and thus a better understanding of the relationships between plants and their pollinators and dispersers (Galetti et al. 2006). Additionally, knowledge about

Correspondence to: Mainara Figueiredo Cascaes

E-mail: mainaracascaes@hotmail.com the reproductive phenology of plants generates data that support restoration programs of degraded areas and management of protected areas (Rego and Lavaronti 2007), and currently is being used as a tool for monitoring climate change (Morellato 2008).

In temperate regions, the climate is strikingly seasonal and directly influences the life cycle of plants (Morellato 1992). In tropical regions, climatic variations are less pronounced, leading to different plant responses in relation to climate (Marques 2007). Phenological studies developed 
in forest communities in Brazil are still limited and are mainly concentrated in the southeast, which has a strong seasonal climate, resulting in distinct phenological patterns, primarily related to rainfall (Morellato 1995). The south of Brazil represents an ecotone between the tropical and subtropical climate, which is characterized by low seasonality, with welldistributed rainfall without a dry season (Marques 2007). Therefore, the phenological patterns in these areas are more related to temperature and photoperiod (Morellato et al. 2000, Talora and Morellato 2000).

Most studies that address phenological events are only carried out with arboreal components, where studies that identify patterns in other lifeforms, such as lianas and herbs, are scarce (Spina et al. 2001, Morellato 2007). However, different life-forms may respond differently to climatic factors, since the morphological and physiological adaptations reflect different ways in which plants capture and use water and nutrients (Smith-Ramirez and Armesto 1994, Marques et al. 2004).

The seasonal development of plant species has a large influence on animal populations, since reproductive phenological cycles can be regulated due to competition between pollinators and seed dispersers, which depend on the resources offered by plants (Obermuller et al. 2008). The temporal availability of flowers and fruits is a relevant subject, as they provide resources to certain groups of animals, ensuring that these animals remain within the forest fragments (Cara 2006).

Riparian forests are characterized as vegetation surrounding water resources. They play an important role in ecosystem maintenance by minimizing processes such as erosion and consequent silting of water sources and also provide ecological connectivity and thus species gene flow (Martins 2001). In the Atlantic Forest, riparian forests were deforested and suffered strong anthropic pressure, which currently results in notorious impacts such as increase of dryness and inundations (Schäffer and Prochnow 2002).
Despite the relevant information generated, there are very few studies that deal with phenological patterns of riparian forests in Brazil, especially for the southern region, where only two studies have been conducted, one by Zocche and Alexander (2005) in Rio Três Cachoeiras, Laguna, Santa Catarina state and the other by Athayde et al. (2009) in Santa Maria, Rio Grande do Sul state.

The present study aims to describe the reproductive phenophases of flowering and fruiting plant species and correlate them with climatic variables of a riparian forest in a conservation unit in Santa Catarina state, Brazil.

\section{MATERIALS AND METHODS}

STUDY SITE

This study took place in the Serra Furada State Park, an integral conservation unit between the municipalities of Orleans and Grão-Pará $\left(49^{\circ} 25^{\prime}\right.$ ' $17^{\prime \prime}$ and $49^{\circ} 22^{\prime} 58^{\prime \prime} \mathrm{W}, 28^{\circ} 08^{\prime} 13^{\prime \prime}$ and $28^{\circ} 11^{\prime} 36^{\prime \prime} \mathrm{S}$ ), with an area of approximately 1,329 ha.

The climate type is $\mathrm{Cfb}$ of the Köppen classification system (Köppen 1931), that is, humid and mesothermic with mild summers and no pronounced dry season. The climatic diagram of the municipality of Orleans (Fig. 1) was constructed with temperature and rainfall data provided by Epagri/Urussanga, over a period of 30 years (1961-1990). The diagram indicates welldistributed rainfall throughout the year, with annual rainfall ranging between 1,300 and 1,600 $\mathrm{mm}$, with December to March receiving the greatest rainfall. The average annual temperature varied from $18.8^{\circ} \mathrm{C}$ to $19.2^{\circ} \mathrm{C}$, with warm period from December to March and cool period from May to July.

The Serra Furada State Park is situated in the phytoecological region of the dense rainforest, involving submontane formations at the base of the slopes, montane in the middle, and upper montane at the top of the slopes. The surrounding areas, predominantly at submontane and montane levels, 


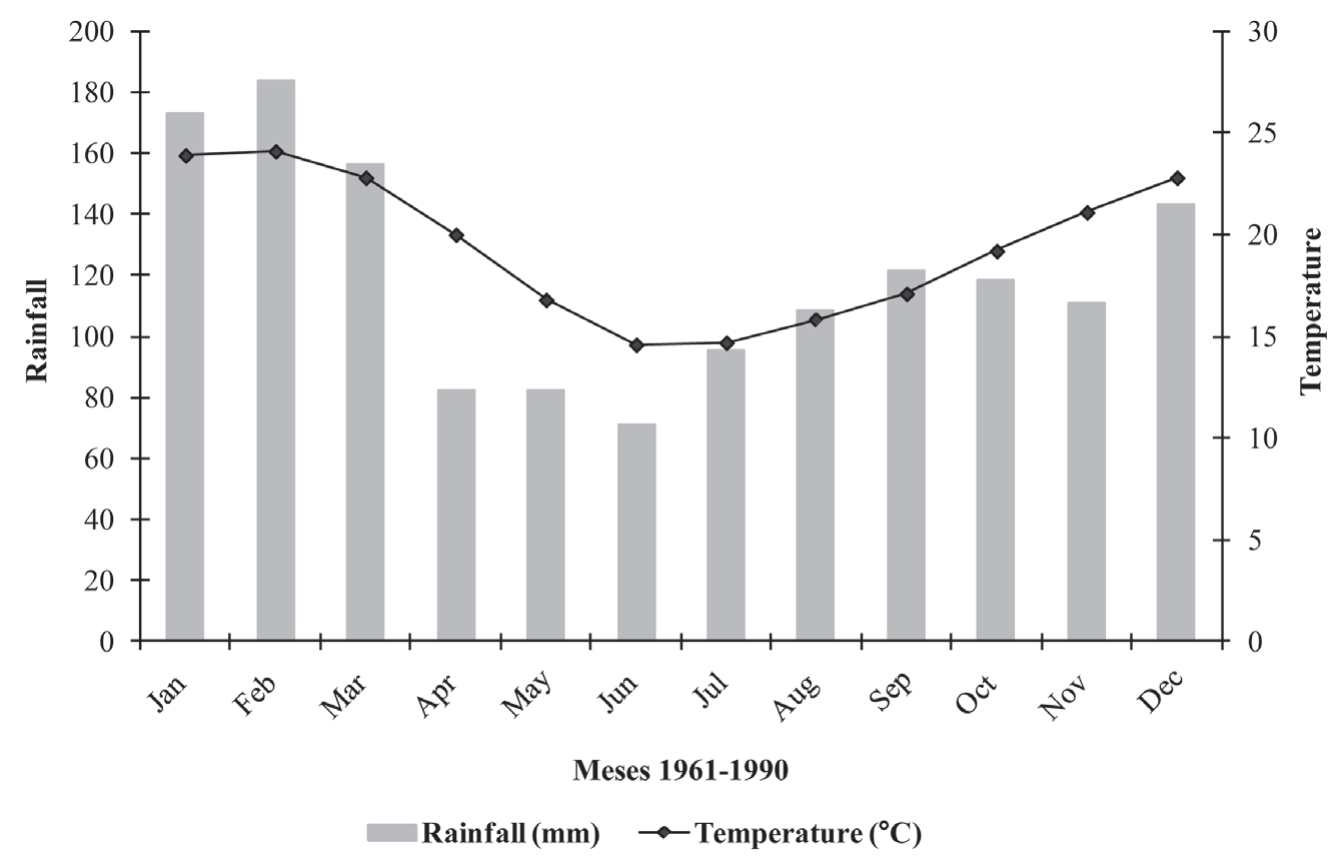

Fig. 1 - Climatic diagram of the municipality of Orleans over a period of 30 years (1961-1990).

are characterized by agricultural activities as well as plantations of exotic species (Management Plan for the Serra Furada State Park, unpublished data).

\section{PHENOLOGICAL REPRODUCTIVE OBSERVATIONS}

In this study, the observations and collections were conducted in dense montane riparian rainforest area (Rodrigues 2000), corresponding to approximately one hectare of the total area of the park. The part of river and riparian forest studied is located in the Braço do Norte river basin, more specifically in the sub-basin of the Meio River (28 $8^{\circ} 11^{\prime} 05.83^{\prime \prime}$ S 49 23 '20.79" W). According to the Brazilian Forest Code (Brasil 2012), $30 \mathrm{~m}$ on each side of the river was considered as riparian forest.

The plant community was observed from November 2010 to October 2011, biweekly, by random pathways. The following terrestrial life-forms were included in the phenological observations: herbs, lianas, shrubs, treelets (understory trees), and trees (including palms), where individuals with a dbh $\geq 5 \mathrm{~cm}$ were considered trees.
When monitoring the reproductive phenophases, one to five individuals of the species were individually marked, and their canopies were observed from the ground. For each plant species observed in the fertile stage, one branch was collected for subsequent identification. In the laboratory, the plant samples were herborized, identified, and deposited by botanists of the Herbarium Pe. Dr. Raulino Reitz (CRI) at the Universidade do Extremo Sul Catarinense (UNESC), and organized into families, according to the delineations of APG III (2009).

The occurrence of reproductive phenophases was qualitatively assessed from direct observation of the marked plants, where the presence or absence of a phenophase was recorded (Bencke and Morellato 2002). In this study, the presence of floral buds and opened flowers was considered as flowering period and the presence of unripe and ripe fruits was considered as fruiting period.

The duration of a phenophase was determined as the period when the first individual entered the phenophase until the last individual left them. 
The data on average monthly temperature and rainfall during the study period was obtained from the Epagri/Urussanga experimental station, and the data on day length was calculated for the study area, using latitude data with the methodology described in Allen et al. (1998), considering the 15th day of each month in the calculation.

\section{DATA ANALYSIS}

The flowering and fruiting phenophases were correlated with climatic variables of rainfall, temperature, and day length. Due to normality of data, Pearson correlation $(p=0.05)$ was applied for analysis using the software PAST 2.04 (Hammer et al. 2010). Multiple regression analysis was performed between phenophases and climatic variables, using the stepwise method of SPSS 17.0 (Norusis 2008), to verify the importance of all variables together (Marques et al. 2004).
The seasonality of the community was tested with circular statistics using the software Oriana 1.03 (Kovach 2010). For this analysis, flowering was divided into buds and anthesis, and fruiting was divided into unripe and ripe fruits. Circular histograms were constructed with the frequency distributions of species in each phenophase during a year (from November/2010 to October/2011), at monthly intervals, when November was considered $0^{\circ}$ and each observation period of 30 days corresponded to $30^{\circ}$ (Morellato et al. 1989).

\section{RESULTS}

The reproductive phenophases of 51 species belonging to 32 families were monitored during the study period, in which 49 species were identified at species level and two were identified at genus level (Table I). Of the 51 species, 31 belonged to tree life-form, six treelets, six shrubs, five lianas, and three herbs.

TABLE I

Reproductive phenophases behavior, life-form, and period of phenophases occurrence of each species observed during the study year.

\begin{tabular}{|c|c|c|c|c|c|}
\hline \multirow{2}{*}{ Families/Species } & \multirow{2}{*}{ Life-forms } & \multicolumn{2}{|c|}{ Flowering } & \multicolumn{2}{|c|}{ Fruiting } \\
\hline & & Period & $\mathbf{N}^{0}$ months & Period & $\mathrm{N}^{0}$ months \\
\hline \multicolumn{6}{|l|}{ Acanthaceae } \\
\hline Justicia carnea Lindl. & Shrub & Nov-Dec & 2 & - & - \\
\hline Justicia floribunda (C. Koch) Wasshausen & Shrub & Jun-Sep & 4 & - & - \\
\hline \multicolumn{6}{|l|}{ Aquifoliaceae } \\
\hline Ilex paraguariensis A. St.-Hil. & Tree & Oct & 1 & Nov & 1 \\
\hline \multicolumn{6}{|l|}{ Araliaceae } \\
\hline Schefflera angustissima (Marchal) Frodin & Tree & Aug-Sep & 2 & Jan & 1 \\
\hline \multicolumn{6}{|l|}{ Arecaceae } \\
\hline Bactris setosa Mart. & Plam tree & - & - & Feb-Apr & 3 \\
\hline Euterpe edulis Mart. & Palm tree & - & - & $\begin{array}{c}\text { Nov-Feb, Jun, } \\
\text { Oct }\end{array}$ & 6 \\
\hline \multicolumn{6}{|l|}{ Asteraceae } \\
\hline Piptochapha cf. angustifolia Dusén ex Malme & Tree & Oct & 1 & - & - \\
\hline Vernonanthura discolor (Spreng.) H.Rob. & Tree & Oct & 1 & - & - \\
\hline Vernonanthura puberula Less. & Tree & Sep-Oct & 2 & - & - \\
\hline \multicolumn{6}{|l|}{ Begoniaceae } \\
\hline Begonia fruticosa (Klotzsch) A.DC. & Herb & $\begin{array}{l}\text { Nov, Jan- } \\
\quad \text { Mar }\end{array}$ & 4 & $\begin{array}{l}\text { Nov, Feb-Apr, } \\
\text { Jun-Jul }\end{array}$ & 6 \\
\hline
\end{tabular}


TABLE I (continuation)

\begin{tabular}{|c|c|c|c|c|c|}
\hline \multirow{2}{*}{ Families/Species } & \multirow{2}{*}{ Life-forms } & \multicolumn{2}{|c|}{ Flowering } & \multicolumn{2}{|c|}{ Fruiting } \\
\hline & & Period & $\mathrm{N}^{0}$ months & Period & $N^{0}$ months \\
\hline \multicolumn{6}{|l|}{ Begoniaceae } \\
\hline Begonia cf. angulata Vell. & Herb & Dec-Jan & 2 & Nov-Dec, Jun & 3 \\
\hline Begonia sp. & Herb & Nov-Jan & 3 & Nov-Jan & 3 \\
\hline \multicolumn{6}{|l|}{ Celastraceae } \\
\hline Maytenus robusta Reissek. & Tree & Jul-Aug & 2 & - & - \\
\hline \multicolumn{6}{|l|}{ Clusiaceae } \\
\hline Clusia criuva Cambess. & Tree & - & - & Oct & 1 \\
\hline \multicolumn{6}{|l|}{ Cucurbitaceae } \\
\hline cf. Fevillea trilobata L. & Liana & - & - & Dec-Feb & 3 \\
\hline \multicolumn{6}{|l|}{ Euphorbiaceae } \\
\hline Alchornea sidifolia Müll. Arg. & Tree & Nov & 1 & Dec & 1 \\
\hline Actinostemon concolor (Spreng.) Müll. Arg. & Treelet & - & - & Oct & 1 \\
\hline \multicolumn{6}{|l|}{ Fabaceae } \\
\hline Ormosia arborea (Vell.) Harms & Tree & - & - & Jul-Oct & 4 \\
\hline \multicolumn{6}{|l|}{ Gesneriaceae } \\
\hline Nematanthus tessmannii (Hoehne) Chautems & Liana & Feb-Oct & 9 & Dec-Jan, Oct & 3 \\
\hline \multicolumn{6}{|l|}{ Heliconiaceae } \\
\hline Heliconia farinosa Raddi & Herb & Nov & 1 & - & - \\
\hline \multicolumn{6}{|l|}{ Lauraceae } \\
\hline Cinnamomum glaziovii (Mez) Kosterm. & Tree & Oct & 1 & - & - \\
\hline Ocotea silvestris Vattimo-Gil & Tree & - & - & Nov-Jan, Oct & 4 \\
\hline Ocotea sp. & Tree & - & - & Apr & 1 \\
\hline \multicolumn{6}{|l|}{ Magnoliaceae } \\
\hline Magnolia ovata (A. St.-Hil.) Spreng. & Tree & - & - & Jun-Oct & 5 \\
\hline \multicolumn{6}{|l|}{ Malvaceae } \\
\hline Byttneria australis St.- Hill. & Liana & Nov & 1 & - & - \\
\hline \multicolumn{6}{|l|}{ Melastomataceae } \\
\hline Leandra dasytricha (A.Gray) Cogn. & Treelet & Nov-Dec & 2 & - & - \\
\hline Miconia cabucu Hoehne & Tree & Aug-Oct & 3 & Nov-Dec & 2 \\
\hline Miconia latecrenata (DC.) Naudin & Treelet & $\begin{array}{l}\text { Nov, Sep- } \\
\text { Oct }\end{array}$ & 3 & Feb-Jul & 6 \\
\hline \multicolumn{6}{|l|}{ Meliaceae } \\
\hline Cabralea canjerana (Vell.) Mart. & Tree & Oct & 1 & Nov-Oct & 12 \\
\hline Cedrela fissilis Vell. & Tree & Nov & 1 & - & - \\
\hline \multicolumn{6}{|l|}{ Moraceae } \\
\hline $\begin{array}{l}\text { Sorocea bonplandii (Baill.) W.C. Burger, } \\
\text { Lanjouw \& Boer }\end{array}$ & Treelet & Dec, Aug & 2 & Nov & 1 \\
\hline \multicolumn{6}{|l|}{ Myrtaceae } \\
\hline Myrcia anacardiifolia Gardner & Tree & $\begin{array}{l}\text { Jan-Mar, } \\
\text { Jul }\end{array}$ & 4 & $\begin{array}{l}\text { Feb, May-Jun, } \\
\text { Aug-Sep }\end{array}$ & 5 \\
\hline Myrcia spectabilis DC. & Tree & Feb-Mar & 2 & Mar-Oct & 8 \\
\hline
\end{tabular}


TABLE I (continuation)

\begin{tabular}{|c|c|c|c|c|c|}
\hline \multirow{2}{*}{ Families/Species } & \multirow{2}{*}{ Life-forms } & \multicolumn{2}{|c|}{ Flowering } & \multicolumn{2}{|c|}{ Fruiting } \\
\hline & & Period & $\mathbf{N}^{0}$ months & Period & $\mathbf{N}^{0}$ months \\
\hline \multicolumn{6}{|l|}{ Nyctaginaceae } \\
\hline Guapira opposita (Vell.) Reitz & Tree & Dec & 1 & - & - \\
\hline \multicolumn{6}{|l|}{ Onagraceae } \\
\hline Fuchsia regia (Vell.) Munz & Shrub & Nov-Oct & 12 & - & - \\
\hline \multicolumn{6}{|l|}{ Phyllanthaceae } \\
\hline Hieronyma alchorneoides Allemão & Tree & - & - & Feb & 1 \\
\hline \multicolumn{6}{|l|}{ Piperaceae } \\
\hline Piper aduncum L. & Shrub & - & - & Nov-Jan & 3 \\
\hline \multicolumn{6}{|l|}{ Primulaceae } \\
\hline Myrsine cf. parvula (Mez) Otegui & Tree & Jul-Aug & 2 & Aug-Oct & 3 \\
\hline \multicolumn{6}{|l|}{ Rubiaceae } \\
\hline Bathysa australis (A.St.-Hil.) K.Schum. & Tree & Nov-Mar & 5 & Apr-Aug & 5 \\
\hline $\begin{array}{l}\text { Posoqueria latifolia (Rudge) Roem. \& } \\
\text { Schult. }\end{array}$ & Tree & Dec-Jan & 2 & $\begin{array}{l}\text { Nov-Dec, Mar- } \\
\text { May, Jun-Oct }\end{array}$ & 10 \\
\hline Psychotria brachyceras Müll. Arg. & Shrub & - & - & Nov-Jul & 9 \\
\hline Psychotria cf. suterella Müll. Arg. & Shrub & Mar & 1 & Mar-Jul & 5 \\
\hline Psychotria vellosiana Benth. & Tree & Nov & 1 & Dec, Jun-Jul & 3 \\
\hline Rudgea jasminoides (Cham.) Müll. Arg. & Tree & $\begin{array}{l}\text { Nov-Dec, } \\
\text { Oct }\end{array}$ & 3 & Mar-Oct & 8 \\
\hline \multicolumn{6}{|l|}{ Rutaceae } \\
\hline Esenbeckia grandiflora Mart. & Treelet & - & - & Nov-Aug & 10 \\
\hline \multicolumn{6}{|l|}{ Sabiaceae } \\
\hline Meliosma sellowii Urb. & Tree & Sep-Nov & 3 & - & - \\
\hline \multicolumn{6}{|l|}{ Salicaceae } \\
\hline Casearia sylvestris Sw. & Tree & Oct & 1 & - & - \\
\hline \multicolumn{6}{|l|}{ Sapindaceae } \\
\hline Cupania vernalis Cambess. & Tree & - & - & Jan & 1 \\
\hline \multicolumn{6}{|l|}{ Solanaceae } \\
\hline $\begin{array}{l}\text { Brunfelsia pauciflora (Cham. \& Schlecht) } \\
\text { Benth. }\end{array}$ & Herb & Nov-Dec & 2 & - & - \\
\hline Solanum pseudoquina A. St.-Hill. & Treelet & Jan & 1 & - & - \\
\hline \multicolumn{6}{|l|}{ Winteraceae } \\
\hline Drimys brasiliensis Miers & Tree & Mar & 1 & May-Jul & 3 \\
\hline
\end{tabular}

During the study year, the climate was more humid than the climatic average, with $2,245 \mathrm{~mm}$ of annual rainfall, in which the rains were poorly distributed and concentrated in two peaks, the first in January and February, and the second in August. The average temperature during this study was $19.4^{\circ} \mathrm{C}$, showing similar trends to the averages from the last 30 years.

Flowering occurred throughout the year, exhibiting an increase in number of species flowering in October, November, and December. The flowering peak month of the studied community was November 
(15 species). There was a decrease in the number of species in blossom in April, May, and June.

The flowering period per species varied from 1 to 12 months, when around $70 \%$ of species presented short flowering periods, ranging from 1 to 2 months. Only two species were observed flowering during longer periods: Fuchsia regia (12 months) and Nematanthus tessmanni (9 months) (Table I).

The circular statistics showed that the average date of the phenophases of floral buds and opened flowers occurred in November (Figure 2 A-B) and were significantly seasonal (Table II).

The Pearson correlations between flowering and climatic variables were significantly positive only between flowering and photoperiod $(r=0.73$, $\mathrm{p}=0.006$ ). However, the multiple regressions showed the average temperature and photoperiod $\left(r^{2}=0.84, p<0.01\right)$ as the best model to explain the seasonality of phenophases.

Fruiting occurred during the entire study year, with an increase of fruiting species in June (16 species) and a slight decrease in August and September. Only the ripe fruits were significantly seasonal (Table II), with the average date in December (Figure 2 C-D). The fact that unripe fruits did not show significant seasonality may be related to the low number of species found in this phenophase $(n=12)$. Despite being considered a seasonal event, fruiting did not show correlation with climatic variables, even though its peak was located in the driest season.
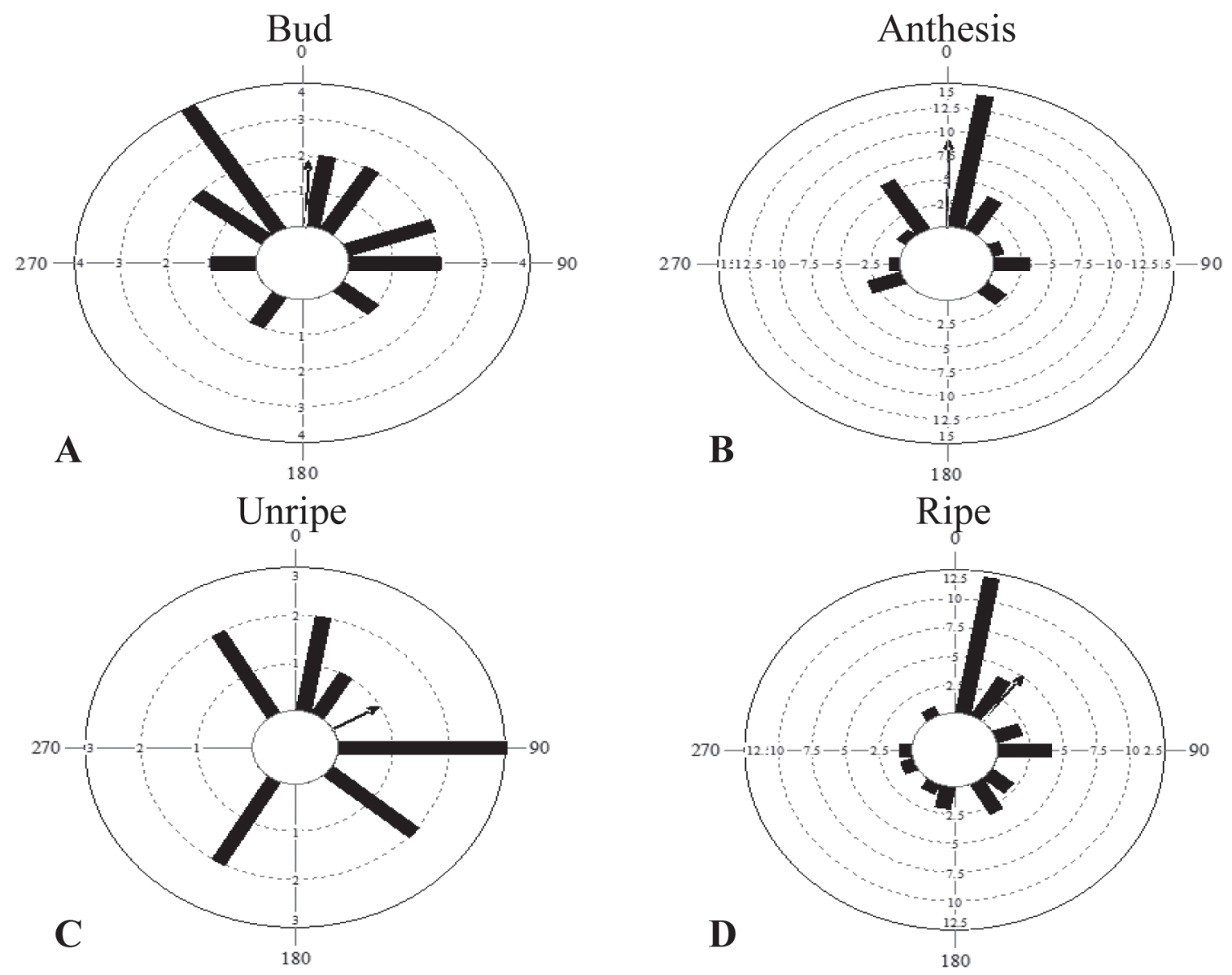

Fig. 2 - Circular histograms at monthly intervals of species in each phenophase of flowering divided into floral buds and open flowers $(\mathbf{A}, \mathbf{B})$ and of fruiting divided into unripe and ripe fruits $(\mathbf{C}, \mathbf{D})$. The arrow indicates the average date of phenophase occurrence; the vector length indicates the species concentration around this date. 
TABLE II

Circular statistical analysis of the seasonality occurrence in reproductive phenophases behavior during the study year. The Rayleigh test verified the significance of the vector mean or mean date (* refers to significant $p$ values $<0.05$, ** refers to significant $p$ values $<0.01$ ).

\begin{tabular}{|c|c|c|c|c|}
\hline \multirow[b]{2}{*}{ Phenophase } & \multicolumn{4}{|c|}{ Inicial Date (2010 - 2011) } \\
\hline & $\mathbf{N}$ & $\begin{array}{c}\text { Mean } \\
\text { Vector } \\
\text { (Month) }\end{array}$ & $\begin{array}{c}\text { Length } \\
\text { of Mean } \\
\text { Vector (R) }\end{array}$ & $\begin{array}{c}\text { Rayleigh } \\
\text { (Z) }\end{array}$ \\
\hline Floral buds & 17 & $\begin{array}{l}2.676^{\circ} \\
\text { (Nov) }\end{array}$ & 0.461 & $3.614 *$ \\
\hline $\begin{array}{l}\text { Oppened } \\
\text { flowers }\end{array}$ & 35 & $\begin{array}{l}0.363^{\circ} \\
\text { (Nov) }\end{array}$ & 0.605 & $12.794 * *$ \\
\hline $\begin{array}{l}\text { Unriped } \\
\text { fruits }\end{array}$ & 12 & $60^{\circ}(\mathrm{Jan})$ & 0.311 & 1.161 \\
\hline Riped fruits & 33 & $\begin{array}{c}37.997^{\circ} \\
(\mathrm{Dec})\end{array}$ & 0.399 & $5.243 * *$ \\
\hline
\end{tabular}

The duration of fruiting varied from 1 to 12 months, when about $60 \%$ of the sampled fruiting species present a short fruiting period, ranging from 1 to 4 months. Five species showed extended
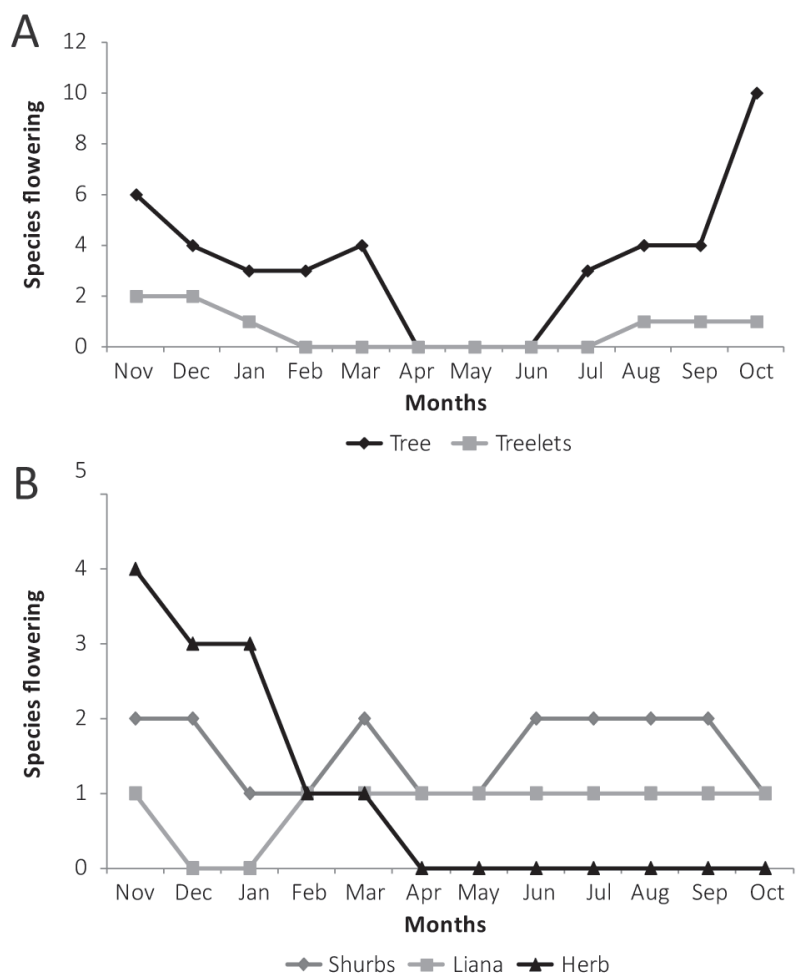

fruiting periods, which were Myrcia spectabilis and Rudgea jasminoides fruiting 8 months each, Esenbeckia grandifolia and Posoqueria latifolia fruiting 10 months each, and Cabralea canjerana, which produced fruits for 12 months (Table I).

When analyzing the species by life-form for the flowering phenophase, the formation of two distinct groups was found. The first group is composed of trees and treelets and the second group by shrubs, herbs, and lianas. The trees flowering peak was concentrated in October and the shrubs demonstrated two peaks in March and another between July and September (Figure 3A). Lianas, herbs, and treelets exhibited a flowering peak in November (Figure 3B).

For the fruiting phenology, trees were the most effective strata, producing fruits year-round. Treelets showed fruit throughout the year except in September (Figure 3C). Lianas were observed with fruits only in December, January, and October. Among the shrubs, it was observed that the period

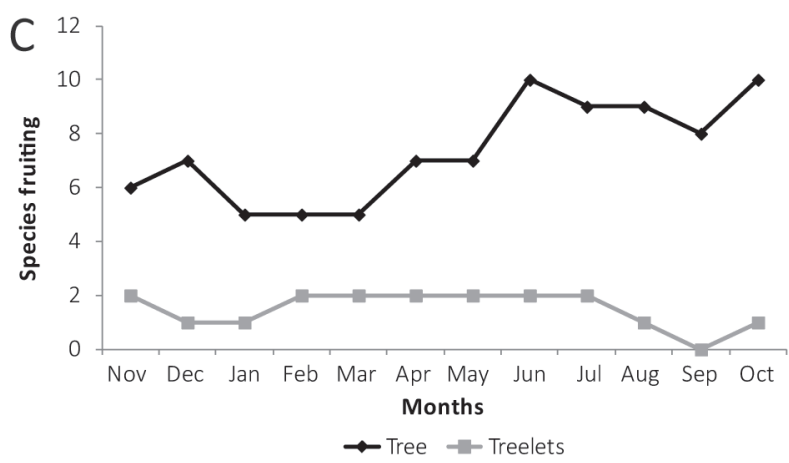

D

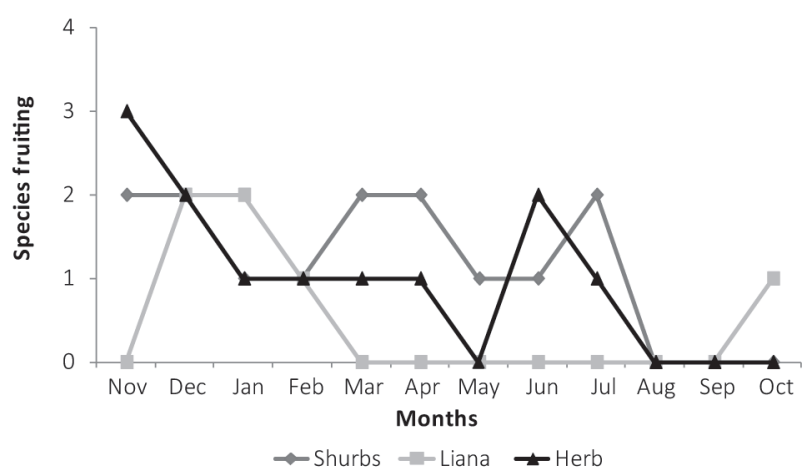

Fig. 3 - Number of flowering (A, B) and fruiting (C, D) species per month during the study year and their relation to life-form. 
of fruiting was concentrated between November and July. Herbs' fruit production was recorded between November and July, with the exception of May (Figure 3D).

\section{DISCUSSION}

Studies conducted in the Atlantic Forest in different phytoecological regions, including riparian forests, point out a seasonal pattern for the flowering phenophase. This seasonal pattern has an increase in number of species and flowering peaks when there is a transition from cool to higher temperatures, which occurs between September and January, affirming the results obtained in this study (Carmo and Morellato 2000, Morellato et al. 2000, Talora and Morellato 2000, Funch et al. 2002, Marques and Oliveira 2004, Marques et al. 2004, Reys et al. 2005, Zocche and Alexandre 2005, Athayde et al. 2009).

The Atlantic Forest is a typical tropical forest (Negrelle 2002), characterized by a no-marked seasonal climate (Morellato et al. 2000, Ziparro and Morellato 2007). Nevertheless, despite the absence of seasonal climate, phenological patterns for this biome have been shown to be seasonal (Marques 2007). In these environments, photoperiod and temperature tend to act as a determinant environmental factor or inducer of flowering, since the oscillations of these climatic variables are related to the increased or decreased rates of flowering (Morellato et al. 2000, Talora and Morellato 2000, Marques and Oliveira 2004, Marques et al. 2004). Due to constant presence of rainfall in these regions, this climate variable is not a determining factor for reproductive phenophases (Morellato et al. 2000, Marques et al. 2004, Ziparro and Morellato 2007).

Regarding fruiting, data obtained in this study compared with studies conducted in the Atlantic Forest indicate a variation in the phenological behavior of this phenophase among different areas. This variation is found both in the availability of fruits throughout the year and fruiting peaks and in the correlation with climatic variables. Marques et al. (2004) evaluated the phenology of an Araucaria forest area and found that the fruiting phenophase was correlated with temperature and photoperiod, but had no significant peak, and showed less seasonality than the flowering phenophase. Morellato et al. (2000) studied four Atlantic Forest areas in São Paulo state and found a tendency among the areas showing that fruiting was a nonseasonal event, with fruiting distributed yearround, peaking in the driest season from March to August. Seasonal patterns for this phenophase exhibited in this study were also found by Talora and Morellato (2000) in a dense rainforest in São Paulo state. In Talora and Morellato (2000), the average date was concentrated in the month of July, the fruiting peak was found in the months of July and August, during the less humid season, and there was a negative correlation with the climatic variables photoperiod, temperature, and rainfall.

Studies in riparian forests also point out different behaviors for fruiting phenology, in which it was shown to be somewhat seasonal (Carmo and Morellato 2000), or with well-defined peaks concentrated in the rainy season (Funch et al. 2002, Reys et al. 2005, Athayde et al. 2009).

The variation in fruiting patterns and the oscillations in the correlations with climate in different environments suggest that factors other than climate variables may act to induce fruiting in humid forests (Frankie et al. 1974). According to Morellato et al. (1989), these factors may be related to the presence of pollinators, dispersers, predators, and competitors, which exert a strong influence on phenological behavior.

Marques et al. (2004) suggest that each lifeform show different phenological patterns due to differences in needs, availability, and resource storage. Regarding the behavior of flowering phenology in relation to life-form, it can be noted that the arboreal stratum produced flowers during the biggest part of the year, except in April, May, 
and June, when no species of this life-form were found flowering. During this period, there was a replacement of species in blossom, with a predominance of shrubs and lianas. In relation to the flowering peaks, with the exception of shrubs, the other life-forms have their flowering peaks in the transition from the cool to warmer period. When analyzing life-forms and phenological fruiting behavior, it was not possible to observe a prominent replacement among life-forms, similar to what was found for flowering.

Patterns in duration of reproductive phases are rarely discussed in phenological studies. However, this can be an important tool to detect interspecies relationships, when associated with the reproductive systems of the species. In this study, two ornithophilous species (F. regia and N. tessmanni) and four zoochorous species (M. spectabilis, $R$. jasminoides, $P$. latifolia, and $C$. canjerana) showed long periods of flower and fruit production. They may be considered keystone species of the local community, ensuring the permanence of animals, which use them as a food resource.

Studies in loco, that observe flowering and fruiting events in tropical and subtropical areas, are of main importance because they expand the knowledge on the behavior of phenophases and their relationship with climate, generate additional data for plant biology, contribute for use in environmental restoration projects, and thus alleviate the situation of degradation of riparian forests.

\section{ACKNOWLEDGMENTS}

We would like to thank Fundação de Amparo à Pesquisa e Inovação do Estado de Santa Catarina (FAPESC) for granting a graduate scholarship to the first author. To Fundação de Amparo à Tecnologia e Meio Ambiente (FATMA) for allowing the study in the PFSP. To the researchers of the Laboratory of Plant-Animal Interaction, for their assistance in the field and laboratory. The botanists of the Herbarium Padre Dr. Raulino Reitz for the identification of the plant species. To Prof. Alvaro Back for help with statistics, especially with the multiple regression analysis, and for providing the climatic data.

\section{RESUMO}

Estudos fenológicos auxiliam na compreensão dos ecossistemas florestais e na avaliação da disponibilidade dos recursos para fauna, melhorando o entendimento das relações entre as plantas e seus polinizadores e dispersores. O presente estudo tem por objetivo descrever as fenofases reprodutivas de espécies vegetais de uma área de mata ciliar e correlacioná-las com as variáveis climáticas. A fenologia reprodutiva foi analisada quinzenalmente durante um ano, sendo registrada a ausência ou presença de flores/frutos. A fenofase de floração ocorreu durante todo o ano de estudo, apresentando incremento do número de espécies em outubro, novembro e dezembro, tendo no mês de novembro o pico de floração da comunidade estudada. A frutificação ocorreu também durante todo o ano de estudo, com acréscimo de espécies frutificando em junho e uma leve queda nos meses de agosto e setembro. Os dados obtidos neste estudo, quando comparados com outros estudos em diferentes áreas da Mata Atlântica, indicam um padrão sazonal para a fenofase de floração e uma variação na disponibilidade dos frutos ao longo do ano, assim como nos picos de frutificação. Desta maneira, estudos que observam os eventos de floração e frutificação in loco são importantes, visto que contribuem com informações sobre as épocas reprodutivas das espécies para utilização em projetos de restauração ambiental e, desta forma, amenizar a situação de degradação das matas ciliares.

Palavras-chave: floração, frutificação, mata ciliar, relações climáticas.

\section{REFERENCES}

Allen RG, Perera LS, Raes D And Smith M. 1998. Crop evapotranspiration - Guidelines for computing crop water requiremients. Roma: FAO Irrigation and drainage paper $56,326 \mathrm{p}$.

APG III - The Angiosperm Phylogeny Group. 2009. An update of the AngiospermPhylogeny Group classification for the ordens and families offlowering plants: APG III. Bot J Linean Soc 161: 105-121. 
Athayde EA, Giehl ELH, BudKe JC, Gesing JPA AND EISINGER SM. 2009. Fenologia de espécies arbóreas em uma floresta ribeirinha em Santa Maria, sul do Brasil. R Bras Bioci 7: 43-51.

Bencke CSC And Morellato LPC. 2002. Comparação de dois métodos de avaliação da fenologia de plantas, sua interpretação e representação. Rev Bras Bot 25: 269-275.

BRASIL. 2012. O Novo Código Florestal Brasileiro. Lei Federal $\mathrm{n}^{\circ}$ 12.651. Brasília: Congresso Federal.

CARA PAA. 2006. Efeito de borda sobre a fenologia, as síndromes de polinização e dispersão de sementes de uma comunidade arbórea na Floresta Atlântica ao norte do Rio São Francisco, Universidade Federal de Pernambuco, Recife, Departamento de Biologia Vegetal, 235 p.

CARMO MRB AND MORELLATO LP. 2000. Fenologia de árvores e arbustos das matas ciliares da bacia do rio Tibagi, Estado do Paraná, Brasil. In: RODRIGUES RR AND LEITÃO-FILHO HF (Eds), Matas Ciliares: conservação e recuperação. $2^{\mathrm{a}}$ ed., São Paulo: Ed. da Universidade de São Paulo/FAPESP, p. 125-141.

FrANKIE GW, BAKER HG AND OPLER PA. 1974. Comparative Phenological Studies of Trees in Tropical Wet and Dry Forests in the Lowlands of Costa Rica. J Ecol 62: 881-919.

FunCH LS, Funch R AND BARRoso GM. 2002. Phenology of gallery and montane forest in the Chapada Diamantina, Bahia, Brazil. Biotropica 34: 40-50.

Galleti M, Pizo MA AND Morellato LPC. 2006. Fenologia, frugivoria e dispersão de sementes. In: CULLEN Jr L, RUDRAN R AND VALLADARES-PADUA C (Eds), Métodos de estudos em biologia da conservação e manejo da vida silvestre. $2^{\mathrm{a}}$ ed., Curitiba: Editora da UFPR, p. 395-422.

HAMMER O, HARPER DAT AND RYAN PD. 2010. PAST: Paleontological statistics software package for education and data analyses. Paleontological eletronica 2.04.

KöPPEN W. 1931. Grundriss der Klimakunde. Gruyter, Berlin, $479 \mathrm{p}$.

KovACH GLD. 2010. Oriana for Windows version 3.0 Kovach Computer Services, Wales: Pentraeth. http://www. kovcomp.co.uk. Cited 12 January 2011.

LIETH H. 1974. Purpose of a phenology book. In: LIETH H (Ed), Phenology and seasonality modeling. New York: Springer Verlag, p. 3-15.

MARQues MCM. 2007. Fenologia no limite sul da região tropical: padrões e algumas interpretações. In: REGO GM, NEGRELLE RRB AND MORELLATO LPC (Eds), Fenologia: ferramenta para conservação, melhoramento e manejo de recursos vegetais arbóreos [recurso eletrônico]. Colombo: Embrapa Florestas, p. 101-110.

MARques MCM AND Oliveira PEAM. 2004. Fenologia de espécies do dossel e do sub-bosque de duas Florestas de Restinga na Ilha do Mel, sul do Brasil. Rev Bras Bot 27: 713-723.

Marques MCM, Roper JJ AND Salvalaggio APB. 2004. Phenological Patterns among Plant Life-Forms in a Subtropical Forest in Southern Brazil. Plant Ecol 173: 203-213.
MARTINS SV. 2001. Recuperação de matas ciliares. Viçosa: Ed. Aprenda Fácil, 255 p.

Morellato LPC. 1992. Sazonalidade e dinâmica de ecossistemas florestais na Serra do Japi. In: MORELLATO LPC (Org), História natural da Serra do Japi: ecologia e preservação de uma área florestal no Sudeste do Brasil. Campinas: Editora da Unicamp/FAPESC, p. 98-111.

MoRellato LPC. 1995. Frutos, frugívoros e a dispersão de sementes. In: MORELLATO LPC and LEITAO FILHO H (Eds), Ecologia e preservação de uma floresta tropical urbana. Campinas: Editora da Unicamp, 136 p.

Morellato LPC. 2007. A pesquisa em fenologia na América do Sul, com ênfase no Brasil, e suas perspectivas atuais. In: REGO GM, NEGRELLE RRB AND MORELLATO LPC (Eds), Fenologia: ferramenta para conservação, melhoramento e manejo de recursos vegetais arbóreos [recurso eletrônico]. Colombo: Embrapa Florestas, p. 37-47.

Morellato LPC. 2008. Fenologia de plantas e os efeitos das mudanças climáticas. In: BUCKERIDGE MS (Org), Biologia \& mudanças climáticas no Brasil. São Carlos: RiMa, p. 181-191.

MORELlato LPC, RODRIGUES RR, LEITÃO-FILHO HF AND JOLY CA. 1989. Estudo comparativo da fenologia de espécies arbóreas de floresta de altitude e floresta mesófila semidecídua na Serra do Japí, Jundiaí, São Paulo. Rev Bras Bot 12: 85-98.

Morellato LPC, Talora DC, Takahasi A, Bencke CC, ROMERA EC AND ZIPPARRO VB. 2000. Phenology of Atlantic Rain Forest Trees: A Comparative Study. Biotropica 32: 811-823.

Negrelle RRB. 2002. The Atlantic Rain Forest in Volta Velha Reserve: a tropical rain forest site outsite the tropics. Biodivers Conserv 11: 887-919.

NORUSIS MJ. 2008. SPSS 17.0 Guide to data analysis. Prentice hall, Upper Saddle River, New Jersey.

Obermuller EA, Nascimento GB, Gava HZ, Ribeiro LF AND Silva AG. 2008. O contraste entre síndromes de polinização e sistemas efetivos de polinização e suas perspectivas para ecossistemas associados à Mata Atlântica. Natureza on line 6: 42-47.

REGO GM AND LAVARONTI OJ. 2007. Atividades fenológicas de Imbuia (Ocotea porosa (NEES T MARTIUS ex NESS) em áreas de Floresta Ombrófila Mista, no estado do Paraná. In: REGO GM, NEGRELLE RRB AND MORELLATO LPC (Eds), Fenologia: ferramenta para conservação, melhoramento e manejo de recursos vegetais arbóreos [recurso eletrônico]. Colombo: Embrapa Florestas, 181-198.

Reys P, Galetti M, Morellato LPC and Sabino J. 2005. Fenologia reprodutiva e disponibilidade de frutos de espécies arbóreas em mata ciliar no rio Formoso, Mato Grosso do Sul. Biota Neotrop 5: 1-10.

RODRIGUES RR. 2000. Florestas ciliares? Uma discussão nomenclatural das formações ciliares. In: RODRIGUES RR AND LEITÃO-FILHO HF (Eds), Matas Ciliares: conservação e recuperação. $2^{a}$ ed., São Paulo: Ed. da Universidade de São Paulo: Fapesp, p. 91-99. 
SCHÄFFER WB AND PROCHNOW M. 2002. Mata Atlântica. In: SCHÄFFER WB AND PROCHNOW M (Orgs), A Mata Atlântica e você: como preservar, recuperar e se beneficiar das mais ameaçadas florestas brasileiras. Brasília; APREMAVI, p. 12-44.

SMith-RAMIREZ C AND ARMeSto JJ. 1994. Flowering and fruiting patterns in the temperate rainforest of Chiloe, Chile - ecologies and climatic constraints. J Ecol 82: 353-365.

SPINA AP, FERREIRA WM AND LEITÃo-FILHO HF. 2001. Floração, frutificação e síndromes de dispersão de uma comunidade de floresta de brejo na região de Campinas (SP). Acta Bot Bras 15: 349-368.
TAlora DC AND Morellato LPC. 2000. Fenologia de espécies arbóreas em floresta de planície litorânea do sudeste do Brasil. Rev Bras Bot 23: 13-26.

ZIPARRO VB AND MOREllato LPC. 2007. Fenologia reprodutiva da comunidade arbórea em floresta atlântica no sudeste do Brasil: um estudo de seis anos. In: REGO GM, NEGRELLE RRB AND MORELLATO LPC (Eds), Fenologia: ferramenta para conservação, melhoramento e manejo de recursos vegetais arbóreos [recurso eletrônico]. Colombo: Embrapa Florestas, p. 113-124.

ZOCCHE JJ AND ALEXANDRE MR. 2005. Fenologia de espécies arbustivo-abóreas das nascentes e margens do Rio Três Cachoeiras, Laguna/SC. Rev tecnol ambient 11: 69-100. 